\title{
Myocardial Gap Junctions: Targets for Novel Approaches in the Prevention of Life-Threatening Cardiac Arrhythmias
}

\author{
N. TRIBULOVÁ, V. KNEZL ${ }^{1}$, L. OKRUHLICOVÁ, J. SLEZÁK \\ Institute for Heart Research, Slovak Academy of Sciences, Bratislava, ${ }^{1}$ Institute of Experimental \\ Pharmacology, Slovak Academy of Sciences, Bratislava, Slovak Republic
}

Received January 25, 2008

Accepted March 25, 2008

On-line March 28, 2008

\begin{abstract}
Summary
Direct cell-to-cell communication in the heart is maintained via gap junction channels composed of proteins termed connexins. Connexin channels ensure molecular and electrical signals propagation and hence are crucial in myocardial synchronization and heart function. Disease-induced gap junctions remodeling and/or an impairment or even block of intercellular communication due to acute pathological conditions results in derangements of myocardial conduction and synchronization. This is critical in the development of both ventricular fibrillation, which is a major cause of sudden cardiac death and persistent atrial fibrillation, most common arrhythmia in clinical practice often resulting in stroke. Many studies suggest that alterations in topology (remodeling), expression, phosphorylation and particularly function of connexin channels due to age or disease are implicated in the development of these life-threatening arrhythmias. It seems therefore challenging to examine whether compounds that could prevent or attenuate gap junctions remodeling and connexin channels dysfunction can protect the heart against arrhythmias that cause sudden death in humans. This assumption is supported by very recent findings showing that an increase of gap junctional conductance by specific peptides can prevents atrial conduction slowing or re-entrant ventricular tachycardia in ischemic heart. Suppression of ischemia-induced dephosphorylation of connexin seems to be one of the mechanisms involved. Another approach for identifying novel treatments is based on the hypothesis that even non-antiarrhythmic drugs with antiarrhythmic ability can modulate gap junctional communication and hence attenuate arrhythmogenic substrates.
\end{abstract}

\section{Key words}

Atrial and ventricular fibrillation • Gap junctions • Connexin channel $\bullet$ Therapeutic targets

\section{Corresponding author}

Narcis Tribulová, Institute for Heart Research, Slovak Academy of Sciences, Dubravska cesta 9, POBox 104, 84005 Bratislava, Slovak Republic. E-mail: narcisa.tribulova@savba.sk

\section{Introduction}

Sudden cardiac death due to ventricular fibrillation (VF) is a major health problem despite of current therapy based on implanted defibrillators (Zipes and Wellens 1998), while atrial fibrillation (AF) is the most common sustained arrhythmia in clinical practice and one of the major causes of stroke (Olsson 2001). Both, AF and VF are considered to occur due to abnormal impulse formation and/or circuit movement re-entry (Gray et al. 1998, Witkowski et al. 1998, Allesie et al. 1984). Re-entry as underlying electrophysiological mechanism of cardiac fibrillation was defined as a persisting electrical impulse that reactivates an area of previously activated myocardial tissues that is no longer refractory, resulting in a circus movement of activation (Janse and Wit 1989). Nevertheless, the molecular and cellular mechanisms involved in the initiation and persistence of these re-entrant arrhythmias in humans are still not fully elucidated. Thus, further investigations are needed for managing of the arrhythmias.

As for AF, various animal models have been proposed to elucidate the factors involved in triggering and sustaining of this arrhythmia as well as to examine the efficacy of antiarrhythmic-defibrillating compounds (Wijffels et al. 1995, Gaspo et al. 1997). In principle, there are three complementary theories dealing with AF. The first one using computer model is based on multiple wavelets of reentrant impulses with short wavelength wandering trough the atria and continuously creating asynchronous electrical activity (Moe et al. 1964). The 
second theory is known as "atrial fibrillation begets atrial fibrillation" (Wijffels et al. 1995). This model is based on the assumption that AF itself leads to tachycardiomyopathy and to electrical remodeling of the atria that results in shortening of wavelength, which facilitates sustaining of AF. The third approach is based on experimental and clinical studies suggesting that myocardial extensions around pulmonary veins are the most important sites for triggering of AF (Olsson 2001), while sustaining of this arrhythmia is linked to a presence of proarrhythmic structural substrates (Spach and Heidlage 1995, Tribulová et al. 1999). More attention to the latter is paid in this review.

As for VF, consistent with theoretical and experimental findings elucidating this arrhythmia, proposed mechanisms focused on "rotors" (Winfree 1974) as transient, unstable object and VF was explained in terms how mother rotors break up into daughter rotors to form turbulent state seen in epicardial maps. Recent work suggests (Chen et al. 2000) that emphasis on the breakup of rotors as the driving force for VF is misplaced. It is proposed (Zaitsev et al. 2000) that the high frequency source is stable rotor, thus reviving the importance of the rotor as the organizing center for VF, with fibrillatory conduction away from the rotor playing a secondary role in the arrhythmia. Mechanisms implicated in initiation and/or maintaining VF are still controversial. Fundamental knowledge about cellular basis of this arrhythmia is essential for designing novel and more effective approaches to prevention and/or treatment, including ICD patients. In this respect cell-to-cell communication via gap junction connexin channels can play a key role as suggest numerous studies included in this article.

The general classification of cardiac arrhythmias assumed that all disturbances of rhythm result from one of two primary abnormalities in electrical activity. The first is an abnormality in impulse initiation and the second, an abnormality in impulse propagation, whereby both may co-exist (Hoffman and Rosen 1981). The former is associated particularly with triggered activity and/or abnormal automaticity, whereas the latter with block of conduction and re-entry. It was hypothesized that intercellular electrical coupling and communication mediated by gap junctions may determine conduction velocity and that alterations in gap junction distribution and/or defective cell-to-cell coupling contribute to abnormal conduction facilitating occurrence of re-entrant arrhythmias, such as AF or VF (Spach et al. 1982, Spach and Starmer 1995, Manoach and Watanabe 1995, Tribulová et al. 2001a, Saffitz et al. 1999, Axelsen et al. 2007, Fialová et al. 2008).

Taking into account that functional cell-to-cell coupling and communication via gap junction connexin channels is crucial for rapid electrical signal propagation and cardiac muscle synchronization, in turn, disorders in cell-to-cell coupling and communication may be a key factor in arrhythmogenesis. In this article we focus, therefore, on gap junction and connexin channels alterations that may underlie proarrhythmia substrates implicated in the development of atrial or ventricular fibrillation in various experimental conditions as well as clinical settings.

\section{Cardiac gap junctions: structure, composition and distribution}

The subcellular structures responsible for myocardial electrical current flow propagation from one cardiac cell to another are specialized connections termed gap junctions (nexuses). There are two types, i.e. end-toend and side-to-side junctions (Figs 1A, 1B). End-to-end type is a part of intercalated disc and it predominates in the cardiac muscle. Lateral gap junctions are much less abundant and occur more often in atrial than ventricular tissues. Conventional patterns of gap junction distribution that can be revealed by immunolabeling (Fig. 1C) underlie uniform anisotropic impulse propagation throughout myocardium (Joyner 1982, Spach and Heidlage 1995).

Gap junctions that link adjoining cardiomyocytes ensure cell-to-cell electrical coupling and direct communication via clusters of intercellular channels (connexons) composed of proteins, termed connexins (Figs 2A, 2B). The heart expresses several connexin isoforms that differ in conductance, whereby connexin-43 (Cx43) predominates in ventricular as well as atrial tissues (Dhein 1998). Besides, Cx40 is abundant in the latter. The half-life of connexins in the adult rat heart is surprisingly short, only about 1.3 hours (Goodenough et al. 1996). The cardiac connexins are phosphoproteins and changes in phosphorylation have been implicated in the regulation of connexin turnover kinetics (Laird 1996). Phosphorylation also appears to play a key role in channel gating that determines channel conductance (Lampe and Lau 2000). Expression and/or gating of connexin channels have been shown modulated by various endogenous and exogenous 



Fig. 1. Electronogram of rat ventricular cardiomyocytes coupled by intercalated disc-related endto-end type ( $\mathrm{A}$, arrows) and lateral side-to-side type ( $\mathrm{B}$, arrow) of gap junctions. Myocardial distribution of both end-to-end (thick arrows) and side-to-side (thin arrows) of Cx43-positive gap junctions is revealed by immunolabeling using specific anti-Cx43 antibodies (C). Magnification $14000 \times(A, B), 80 \times(C)$.

compounds, e.g. hormones, growth factors, eicosanoids, narcotics, protein kinases as well as by abnormal elevation of intracellular ions, such as $\mathrm{Na}^{+}, \mathrm{Ca}^{2+}$ and $\mathrm{H}^{+}$ (for details see Salameh and Dhein 2005).
An effective pump function of the heart requires electrical activation of the myocardium in a specific temporal and spatial pattern and this process is depending in large part on the distribution and function of gap 

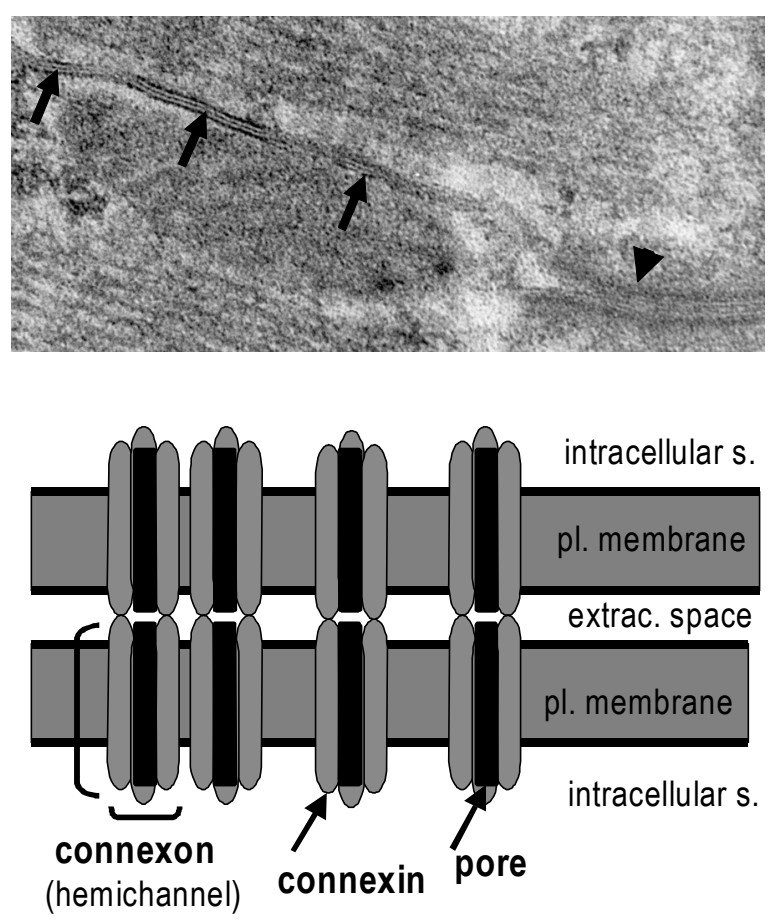

Fig. 2. Details of gap junction structure (arrows), as seen in electron microscope by higher magnification - $30000 \mathrm{x}$. There are two closely apposed unit membranes (black lines arrows) separated by "gap" with transverse densities (middle line). Diagram of gap junction structure shows gap junction channels composed of proteins termed connexins. Each intercellular channel comprises an abutting pair of connexons (hemichannels).

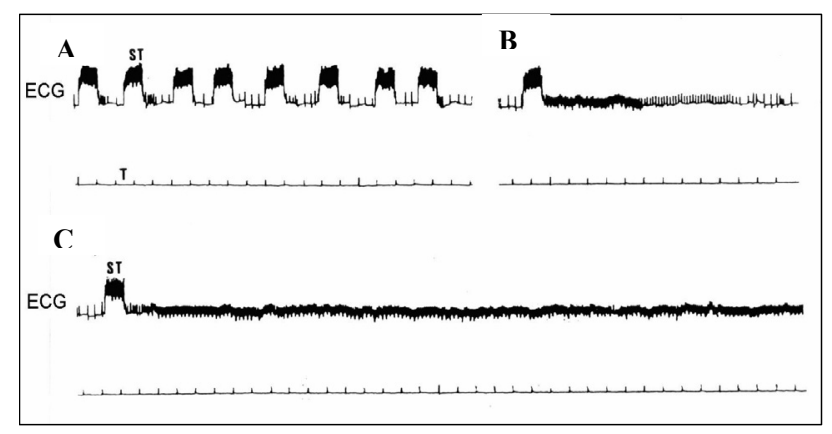

Fig. 3. Electrocardiograms of the atria of guinea pig hearts subjected to electrical burst stimulation to induce atrial fibrillation. Note that intermittent pacing (A) did induce only short-lasting arrhythmias in young (B), while prolonged (15 min) atrial fibrillo-flutter in old guinea pig heart (C). T - time in seconds, (adapted from Tribulová et al. 1999).

junctions. Accordingly, gap junction connexin channels are crucial in direct intercellular communication and myocardial synchronization. Thus, it is very likely that reduced number and/or disturbed myocardial distribution of gap junctions as well as impairment and/or dysfunction of connexin channels can promote cardiac arrhythmias, including AV and VF. Indeed, numerous studies support this assumption.

\section{Cardiac gap junction and $\mathrm{Cx} 43$ alterations implicated in occurrence of $\mathbf{A F}$}

In humans incidence of $\mathrm{AF}$ is known to increase in aged or cardiomyopatic heart. These conditions are characterized by myocardial structural remodeling since the heart changes its structure and function in response to aging, disease or injury. Thus, it alters the structure of the cardiomyocytes and extracellular matrix by activating intracellular signaling cascades. Consequently it results in myocardial hypertrophy and/or fibrosis (Spach and Heidlage 1995, Tribulová et al. 1999, Janse and De Bakker 2001, Mukherjee et al. 2006). Importantly, myocardial structural remodeling is accompanied with gap junction remodeling (Saffitz et al. 1999, Tribulová et al. 1999, 2002a,b, van der Velden et al. 2000, Kostin et al. 2002, Severs 2001) that may be triggered by changes in signaling molecules in response to overall remodeling characteristics (Teunissen et al. 2004). In general, remodeling of gap junctions, i.e. changes in topology of connexin channels, is linked with electrical remodeling contributing to conduction alterations (Papageorgiou et al. 1996, Spach et al. 1982, Wijffels et al. 1995), hence to be considered as an arrhythmogenic substrate.

In agreement with it, it has been shown that burst pacing of guinea pig atria in isolated heart preparation resulted in prolonged AF or fibrillo-flutter in old guinea pigs (Fig. 3) exhibiting pronounced changes in extracellular matrix composition and less gap junction profiles (Fig. 4B), while not in young characterized by normal ultrastructure and numerous gap junctions (Fig. 4A). In parallel, Cx43 expression was significantly decreased in the atria of old comparing to young guinea pigs (Tribulová et al. 1999, 2002b). Likewise

Cx40-deficient mice exhibited high atrial vulnerability to fast pacing-induced tachyarrhythmias (Hagendorff et al. 1999). Reduction in Cx40 was detected in human with chronic AF (Polontchouk et al. 2001) as well as in chronic model of pacing-induced sustained AF in goats (van der Velden et al. 2000). It indicates that downregulation of connexins may also contribute to persistence of AF.

It should be stressed that aging and cardiovascular diseases are, in addition to structural and gap junction remodeling, characterized by abnormal $\mathrm{Ca}^{2+}$ handling (Dhalla et al. 1988, Jiang et al. 1993, Lakatta and Guarneri 1993). Accordingly, it was hypothesized 

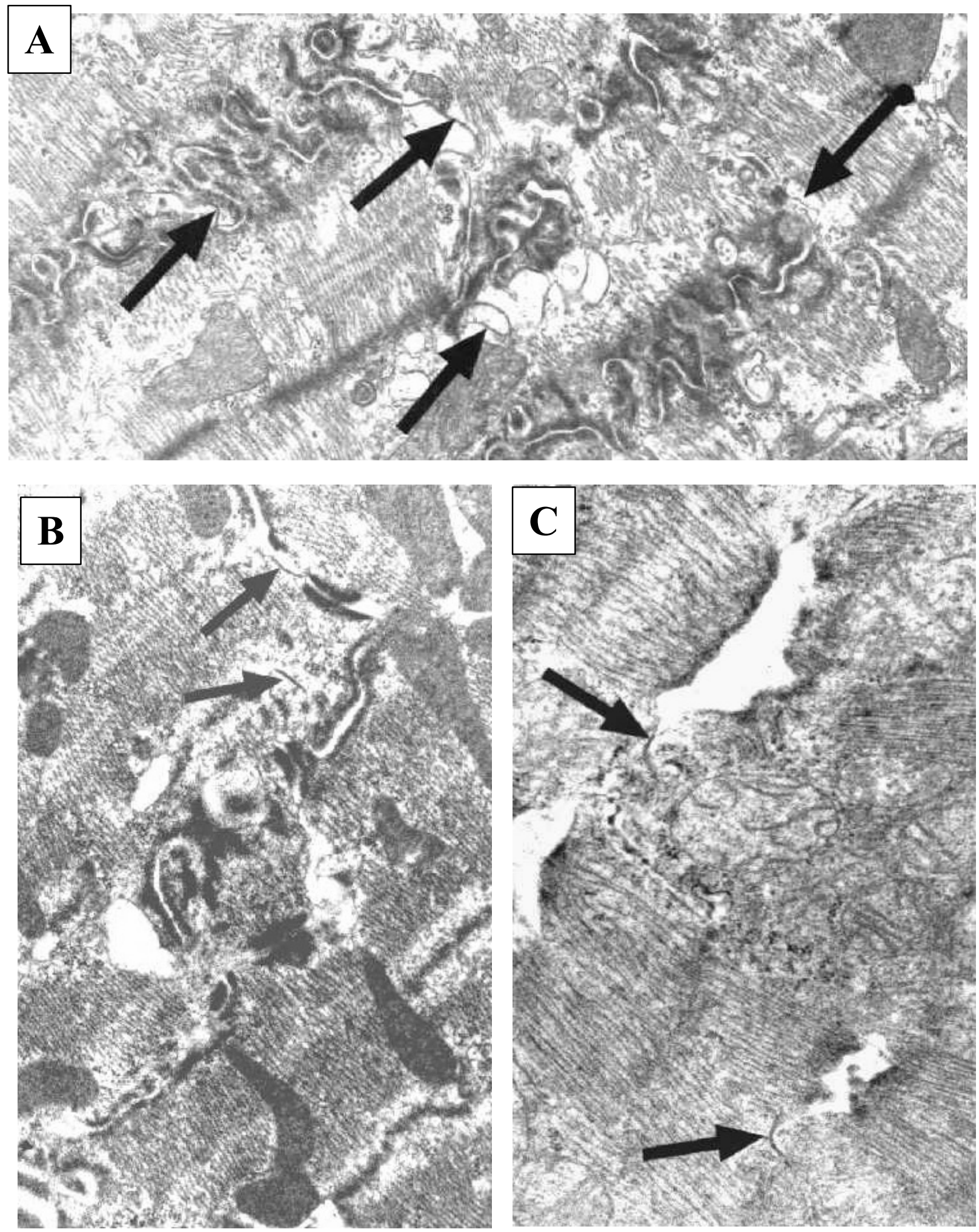

Fig. 4. Subcellular features of cell-to-cell junctions of young $(A)$ and old $(B, C)$ guinea pigs atria. Note numerous gap junctions (arrows) and undulated fascia adherens junctions with narrow intercellular space in young (A), while reduced number of gap junctions (arrows) and flattened fascia adherens junctions with widened extracellular space in old guinea pig myocardium (B). Burst pacing of old guinea pig atria, lasting for 5-15 min, induced subcellular alterations indicating cytosolic $\mathrm{Ca}^{2+}$ disturbances and dehiscence of fascia adherence junctions in the vicinity of (functionally very likely altered) gap junctions (arrows, C). Magnification $18000 \mathrm{x}$. 

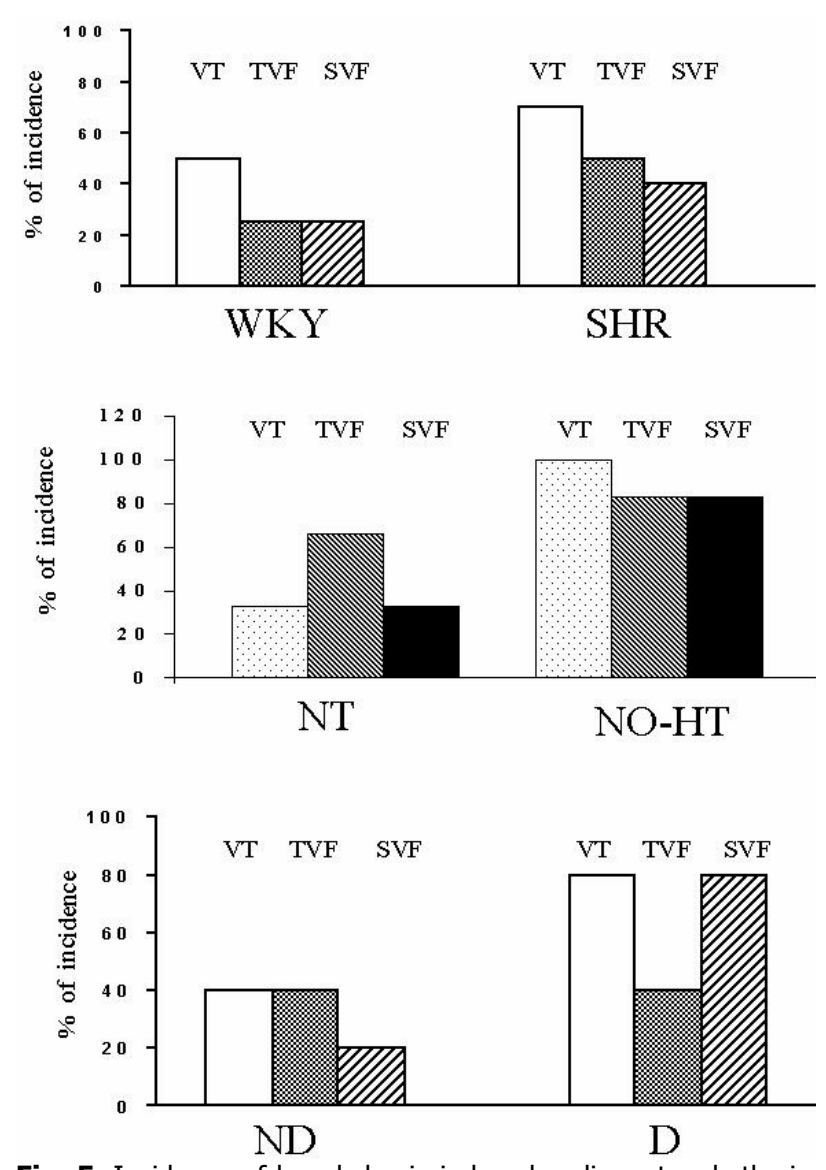

Fig. 5. Incidence of hypokalemia-induced malignant arrhythmias (VT - ventricular tachycardia, TVF - transient ventricular fibrillation, SVF - sustained ventricular fibrillation) in the hearts of rats with spontaneous (SHR) or L-NAME-induced hypertension (NO-HT), or diabetes (D). Note much higher incidence of SVF in disease-affected hearts compared to age-matched healthy controls (adapted from Tribulová et al. 2002b).

that aged or diseased heart due to altered $\mathrm{Ca}^{2+}$ handling is less able to maintain $\mathrm{Ca}^{2+}$ homeostasis, while prone to develop $\mathrm{Ca}^{2+}$-overload. The latter leads to subcellular injury and particularly to impairment of cell-to-cell coupling (or even uncoupling) at the gap junction channels (De Mello 1986, Salameh and Dhein 2005). Consequently it can facilitate occurrence of malignant reentry arrhythmias (Merrilat et al. 1990, Kihara and Morgan 1991, Wang et al. 1997, Tribulová et al. 2002a, 2003) and prevent their termination and sinus rhythm restoration (Manoach et al. 2007). Fast pacing-induced elevation of intracellular $\mathrm{Na}^{+}$(Simor et al. 1997) and consequent activation of $\mathrm{Na} / \mathrm{Ca}$ exchanger can result in disturbances of $\mathrm{Ca}^{2+}$ homeostasis. Indeed, $\mathrm{Ca}^{2+}$ overload has been indicated by presence of hypercontracted sarcomeres and dehiscence of fascia adherens junctions upon intermittent burst pacing (Fig. 4C). Notably, these subcellular changes occurred early (after 5-10 min of burst pacing) and in majority of cardiomyocytes of old guinea pig atria. Unlike to old, young guinea pigs developed high $\mathrm{Ca}^{2+}$-induced injury in minor population of cardiomyocytes and upon prolonged ( $>1$ hour) fast pacing. In addition, immunolabeling revealed that diminished expression and inhomogeneous myocardial distribution of $\mathrm{Cx} 43$ in old guinea pig myocardium aggravated due to burst pacing prior occurrence of $\mathrm{AF}$ (Tribulová et al. 1999, 2002b). These findings suggest acute impairment of cell-to-cell coupling due to, at least in part, pacing-induced $\mathrm{Ca}^{2+}$ elevation. Interestingly, pretreatment of perfused heart with heptanol, a compound that deteriorates electrical coupling and induces cell-tocell uncoupling, promoted inducible $\mathrm{AF}$ in aged rat model (Hayachi et al. 2002).

\section{Cardiac gap junction and $\mathrm{Cx} 43$ alterations implicated in occurrence of VF}

Experimental and clinical studies showed that diseased or failing heart is prone to develop VF, which is main cause of sudden cardiac death particularly during heart attack. Slow conduction and fractionated electrocardiograms were recorded in the infarcted human heart (De Bakker et al. 1993, Gardner et al. 1985). Myocardial tissue analysis revealed pathological substrates, including a decrease and misslocalization of gap junctions, which correlated with location of reentrant circuits in the border zone of infarction (Peters et al. 1997). Interestingly, Cx43-deficient mice exhibited markedly slowing of myocardial conduction that facilitates re-entrant arrhythmias and sudden arrhythmic death (Lerner et al. 2000, Gutstein et al. 2001). Downregulation and/or abnormal distribution of myocardial Cx43-positive gap junctions linked with increased susceptibility to hypokalemia-induced ventricular fibrillation (Fig. 5) have been reported in rats suffering from diabetes mellitus (Okruhlicová et al. 2002) spontaneous or L-NAME-induced hypertension (Tribulová et al. 2002a, 2003, Fialová et al. 2008). While diabetes was associated with myocardial fibrosis, young spontaneously hypertensive rats were characterized by left ventricular hypertrophy and L-NAME-induced hypertension was accompanied by both hypertrophy and fibrosis of the heart (Tribulová et al. 2002b). Reduced gap junction coupling in areas of fibrosis could disrupt wave-front propagation and hence interfere with uniform and synchronized cardiomyocyte function. Likewise, abnormal distribution and lateralization of gap junctions in hypertrophied myocardium can affect uniform 


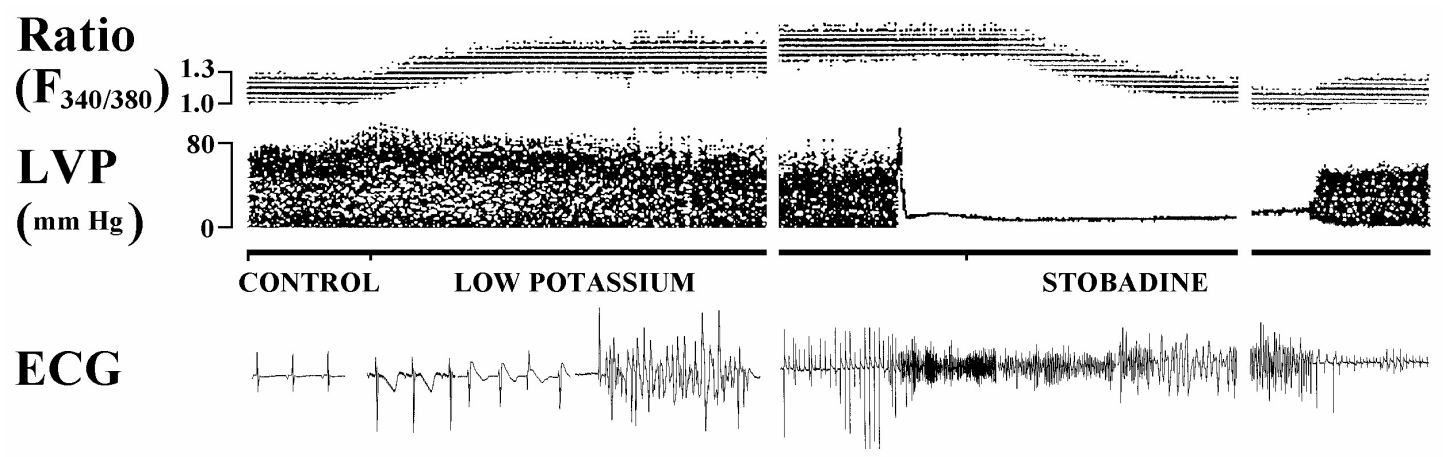

Fig. 6. Original recording of cytosolic $\left[\mathrm{Ca}^{2+}\right] \mathrm{i}$ and left ventricular pressure (LVP) alterations as well as ECG changes occurred prior hypokalemia-induced $V F$, during VF and before sinus rhythm restoration facilitated by stobadine $\left(10^{-6} \mathrm{M}\right)$ in isolated heart preparation. Note a pronounced increase of $\left[\mathrm{Ca}^{2+}\right] \mathrm{i}$ due to perfusion of the heart with $\mathrm{K}^{+}$-deficient solution that was accompanied by transient arrhythmias, which degenerated upon $15-20$ min to $\mathrm{VF}$, while baseline $\left[\mathrm{Ca}^{2+}\right]$ i restoration preceded sinus rhythm restoration.
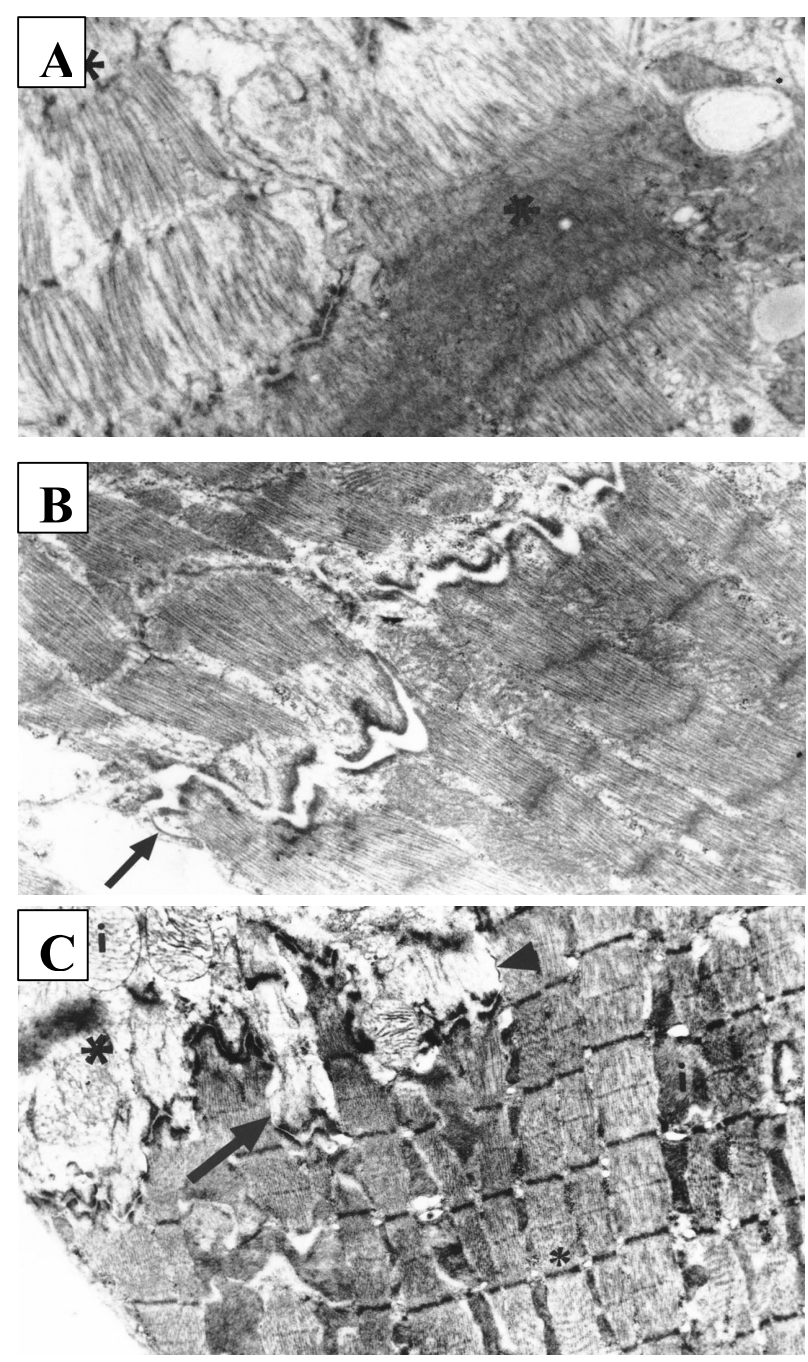

Fig. 7. Subcellular alterations and impairment of cell-to-cell junctions due to hypokalemia-induced $\mathrm{Ca}^{2+}$ overload. Note in $\mathrm{A}$ contraction bands (asterisk) in the vicinity intercellular junctions; in B - relaxed versus contracted cardiomyocytes strongly indicating impaired coupling at the gap junctions (arrow) in the vicinity of dissociated fascia adherence junctions; in C subcellular features indicating cell-to-cell uncoupling when almost normal cardiomyocyte (right) is connected with irreversiblyinjured one (left). Such patterns of deteriorated coupling heterogeneously distributed throughout myocardium preceded occurrence of ventricular fibrillation. Magnification $18000 \times(A$, B), $15000 \times(C)$. anisotropic conduction (Spach et al. 2000). There are changes in electrical properties in the early stage of left ventricular hypertrophy before arrhythmia occurrence (Bacharová 2007). It would be interesting to know alterations in $\mathrm{Cx} 43$ expression in early juvenile period of SHR, which is critical for hypertension (Zicha et al. 2006a). It appears that structural and gap junction remodeling associated with electrophysiological remodeling (Severs 2001, Teunissen et al. 2004) can create arrhythmogenic substrate for triggering and sustaining of cardiac arrhythmias. Myocardial gap junction remodeling linked with increased vulnerability to VF was detected also in hypertriglyceridemic rats (Tribulová et al. 2006), an experimental model of metabolic syndrome (Zicha et al. 2006b).

Perfusion of the heart with $\mathrm{K}^{+}$deficient solution leads to an increase in intracellular $\mathrm{Ca}^{2+}$ concentration (Fig. 6A). Diabetic or hypertensive rat hearts with abnormal $\mathrm{Ca}^{2+}$ handling (Dhalla et al. 1988, Balke and Shorofsky 1998) were much prone to develop high $\mathrm{Ca}^{2+}$ induced ventricular premature beats, compared to controls (Tribulová et al. 2003). Furthermore, acute $\mathrm{Ca}^{2+}$ overload may contribute to disturbances in coordinated contraction likely due to cell-to-cell uncoupling (de Groot and Coronel 2004, Tribulová et al. 2001a). The latter was indicated according non-uniform sarcomere patterns of adjacent cardiomyocytes connected by gap junctions (Fig. 7), i.e., relaxed sarcomeres in one versus contracted in neighboring (Fig. 7B). Total cell-to-cell uncoupling was indicated when two neighboring cardiomyocytes differ in structural appearance, i.e. one with negligible while another with irreversible injury (Fig. 7C). In such case, the uncoupling prevents propagation of "injury current" (De Mello 1989). Myocardial inhomogeneities in Cx43 distribution including patchy areas with abolished immunostaining (Fig. 8) as well as suppression of $\mathrm{Cx} 43$ 

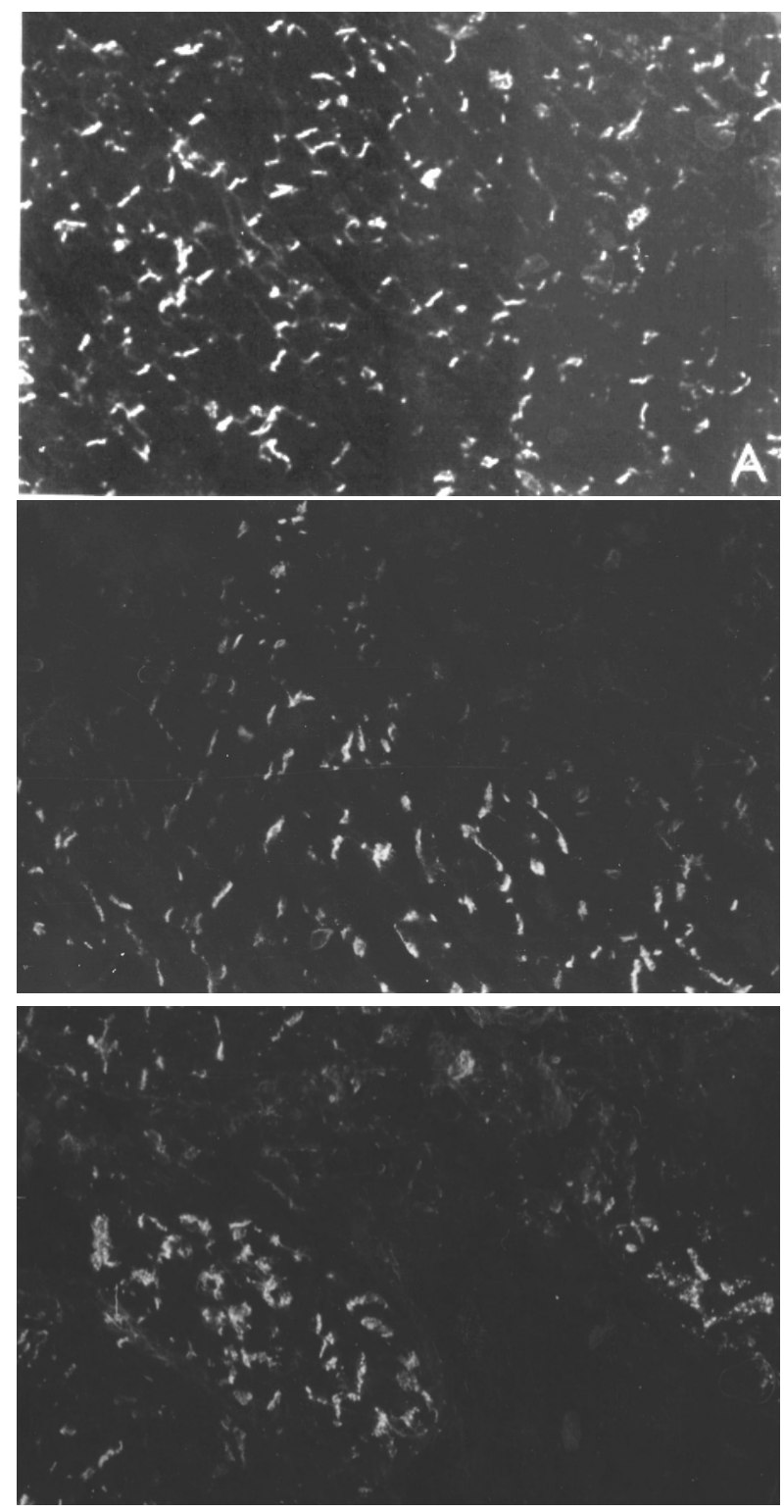

Fig. 8. Immunolabeling of $C x-43$ in the ventricles of isolated rat hearts perfused with standard $(A)$ and low $\mathrm{K}^{+}$solution $(B, C)$. Note uniform distribution of $\mathrm{Cx} 43$-positive gap junctions in (A), while heterogeneously abolished $\mathrm{C} \times 43$ staining during $15 \mathrm{~min}$ of low- $\mathrm{K}^{+}$perfusion prior occurrence of sustained VF $(B, C)$. Magnification $80 \mathrm{x}$.

phosphorylation (Tribulová et al. 2003) strongly suggested cell-to-cell coupling disorders. Similarly, electrical uncoupling due to acute ischemia-induced dephosphorylation of Cx43 (de Groot and Coronel 2004) and its intracellular ventricular redistribution (Beardslee $e t$ al. 2000) were observed. Suppression of phospho-rylated isoforms of $\mathrm{Cx} 43$ in spontaneously hypertensive rat hearts (Fig. 9A) (Tribulová et al. 2003) and young (Fig. 9C) (Lin et $a l$., to be published) unlike to old thyroid hormonetreated rats (Fig. 9B) (Tribulová et al. 2005) was associated with higher vulnerability of the former to hypokalemia-induced VF (Tribulová et al. 2004). Thus, defects in Cx43 expression, phosphorylation and channel function, particularly when heterogeneously distributed throughout myocardium renders the heart prone to VF.

\section{How to prevent AF and VF by targeting cardiac gap junctions?}

Potential mechanisms controlling the level of intercellular communication in the heart include regulation of connexin turnover (synthesis and degradation), cellular distribution and phosphorylation. There are numerous data showing that some compounds can up-regulate $\mathrm{Cx}-43$ via modulation either synthesis or degradation and enhance gap junctional communication (for review see Salameh and Dhein 2005). In contrast, much less information is about causal relationship between the Cx-43 up-regulation and decreased susceptibility to re-entry arrhythmias as well as whether attenuation or regression of gap junctions remodeling will abolish arrhythmogenic substrate resulting in lower arrhythmia incidence. Nevertheless, very recent studies showed (Haugan et al. 2005, Axelsen et al. 2007) that an increase of gap junctional conductance by specific peptide, rotigaptide, can prevent atrial conduction slowing or re-entrant ventricular tachycardia in ischemic heart. Suppression of ischemia-induced dephosphorylation of connexin seems to be one of the mechanisms involved. This mechanism was thought to be involved in the antiarrhythmic effects of ischemic preconditioning (Schulz et al. 2007). It seems that modulation $\mathrm{Cx} 43$ channels function via phospohorylation, which is often linked with intracellular ATP levels (Turner et al. 2004) may be powerful tool to prevent cell-to-cell uncoupling and to enhance gap junctional communication. Similarly, in isolated heart model the abolishment of $\mathrm{Ca}^{2+}$ overload, which was facilitated by stobadine, resulted in termination of VF and sinus rhythm restoration (Fig. 6), most likely due to restoration of intercellular coupling (Tribulová et al. 2001b). This assumption is supported by the findings of others (Dekker et al. 1999, Merrilat et al. 1990). Furthermore, clinical studies indicate that compounds or interventions preventing or attenuating disease-related structural remodeling protect against atrial or ventricular fibrillation (Hanna et al. 2006, Wachtell et al. 2007). While experimental studies showed significant antifibrillating effects of lipid lowering compounds (atorvastatin) and omega-3 fatty acids in 

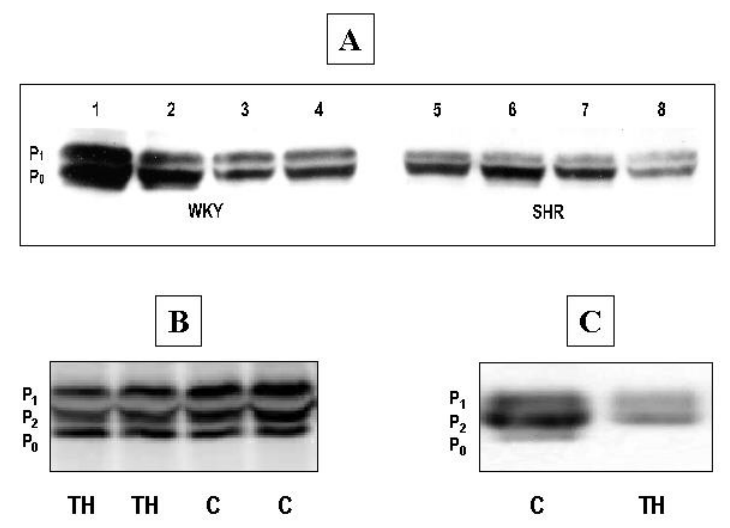

Fig. 9. Representative immunoblots of rat hearts $\mathrm{Cx}-43$ showing its expression and phosphorylated isoforms (P1, P2). Note pronounced reduction of myocardial $\mathrm{Cx}-43$ phosphorylation in spontaneously hypertensive rats (A- SHR, lines 5,6 vs WKY, lines $1,2)$ and $T_{4}$-treated young $(C)$ while not in old rat hearts (B) compared to untreated age-matched controls. $\mathrm{TH}-\mathrm{T}_{4}$-treated rats, $\mathrm{C}-$ control rats.

hypertriglyceridemic and aged male and female SHR rats despite structural and gap junction remodeling was not eliminated (Fialová et al. 2007, Tribulová et al. 2007). However, expression and phosphorylation of $\mathrm{Cx} 43$ was increased. It is important to note that the increased intrinsic level of myocardial Cx43 expression in either healthy or hypertensive female than to male rat hearts (Tribulová et al. 2005, Fialová et al. 2007) is very likely implicated in their decreased susceptibility to VF compared to male (Mitašíková et al. 2008).

\section{Conclusions and perspectives}

It is very interesting that despite of various etiologies (aging, diabetes, hypertension, hyperthyroidism) and triggering factors (fast burst pacing, ischemia or hypokalemia) a similar features of myocardial subcellular and $\mathrm{Cx} 43$ changes have been detected prior occurrence of either atrial or ventricular fibrillation in experimental conditions. The findings suggest that 1) the structural substrates for re-entry mechanism underlying cardiac fibrillations appear to be remodeling of both myocardial architecture (hypertrophy, fibrosis) and gap junctions (abnormal distribution, decreased number); 2) occurrence of atrial or ventricular fibrillation is triggered by acute events, which induce sudden disturbances in electrolyte homeostasis, $\mathrm{Ca}^{2+}$ overload and $\mathrm{Cx} 43$ dephosphorylation deteriorating (or even block) of cell-to-cell cell coupling and communication; 3 ) heterogeneous or focal myocardial distribution of both pre-existing gap junction abnormalities due to age or disease and sudden connexin channels dysfunction due to acute pathophysiological conditions can significantly contribute to myocardial electrical instability rendering the heart prone to malignant arrhythmias.

Taking into account all above mentioned factors and a key role of the gap junction connexin channels in the cardiac arrhythmogenesis, it appears that aimed modulation of intercellular communication to prevent spatial electrical heterogeneities in viable myocardium, is promising way to fight life-threatening arrhythmias and sudden death in human. Nevertheless, more detailed analysis and further studies are needed to address this issue looking for innovative therapeutic approaches.

\section{Conflict of Interest}

There is no conflict of interest.

\section{Acknowledgements}

This work was supported by the Slovak Grant Agencies APVV Grant No. 51-059505, No. 51-017905 and VEGA Grant No. 2/6064/26, 2/5021/26, 2/7094/27.

\section{References}

ALLESIE MA, LAMMERS WJEP, BONKE IM, HOLLEN J: Intra-atrial reentry as a mechanism for atrial flutter induced by acetylcholine and rapid pacing in dog. Circulation 70: 123-135, 1984.

AXELSEN AN, HAUGAN K, STAHLHUT M, KJǾLBYE, HENNAN JK, HOLSTEIN- RATHLOU NH, PETERSEN JS, NIELSEN MS: Increasing gap junctional coupling: a tool for dissecting the role of gap. J Membrane Biol 216: 23-35, 2007.

BACHAROVÁ L: Electrical and structural remodeling in left ventricular hypertrophy: a substrate for a decrease in QRS voltage? Ann Noninvasive Electrocardiol 12: 260-273, 2007.

BALKE CW, SHOROFSKY SR: Alterations in calcium handling in cardiac hypertrophy and heart failure. Cardiovasc Res 37: 290-299, 1998. 
BEARDSLEE MA, LERNER DL, TADROS PN, LAING JG, BEYER EC, YAMADA KA, KLÉBER AG, SCHUESSLER RB, SAFFITZ JE: Dephosphorylation and intracellular redistribution of ventricular connexin43 during electrical uncoupling induced by ischemia. Circ Res 87: 656-662, 2000.

CHEN J, MANDAPATI R, BERENFELD O, SKANES AC, JALIFE J: High frequency periodic sources underlie ventricular fibrillation in the isolated rabbit heart. Circ Res 86: 86-93, 2000.

DE BAKKER JMT, CAPELLE FJ, JANSE MJ, TASSERON S, VERMEULEN JT, DE JONGE N, LAHPOR JR: Slow conduction in the infarcted human heart. "Zigzag" course of activation. Circulation 88: 915-926, 1993.

DE GROOT JR, CORONEL R: Acute ischemia-induced gap junctional uncoupling and arrhythmogenesis. Cardiovasc Res 62: 323-334, 2004.

DEKKER LRC, CORONEL R, VAN BAVEL E, SPAAN AE, OPTHOF T: Intracellular $\mathrm{Ca}^{2+}$ and delay of ischemiainduced electrical uncoupling in preconditioned rabbit ventricular myocardium. Cardiovasc Res 44: 101-102, 1999.

DE MELLO WC: Interaction of cyclic AMP and $\mathrm{Ca}^{2+}$ in the control of electrical coupling in the heart fibers. Biochim Biophys Acta 888: 91-99, 1986.

DE MELLO WC: Cell coupling and healing-over in cardiac muscle. In: Physiology and Pathophysiology of the Heart. SPERELAKIS N (ed), Kluwer Academic Publisher, 1989, pp 541-549.

DHALLA NS, LIU X, PANAGIA V, TAKEDA N: Subcellular remodeling and heart dysfunction in chronic diabetes. Cardiovasc Res 40: 239-247, 1988.

DHEIN S: Gap junction channels in the cardiovascular system: pharmacological and physiological modulation. Trends Pharmacol Sci 19: 229-241, 1998.

FIALOVÁ M, DLUGOSOVÁ K, KNEZL V, OKRUHLICOVÁ L, DŘÍMAL J, TRIBULOVÁ N. Omega-3 fatty acids protect male and female aged hypertensive rat heart against ventricular fibrillation. Acta Physiol Scand 19 (Suppl 658): 88, 2007.

FIALOVÁ M, DLUGOŠOVÁ, OKRUHLICOVÁ L, KRISTEK F, MANOACH M, TRIBULOVÁ N. Adaptation of the heart to hypertension is associated with maladaptive gap junction connexin-43 remodelling. Physiol Res 57: 7-11, 2008.

GARDNER PI, URSEL PC, FENOGLIO JJ, WIT AL: Electrophysiologic and anatomic basis for fractionated electrograms recorded from healed myocardial infarcts. Circulation 72: 596-611, 1985.

GASPO R, BOSH RF, TALAJIC M, NATTEL S: Functional mechanisms underlying tachycardia-induced sustained atrial fibrillation in a chronic dog model. Circulation 96: 4027-4035, 1997.

GOODENOUGH DA, GOLIGER JA, PAUL DL: Connexin, connexons and intercellular communication. Annu Rev Biochem 65: 475-502, 1996.

GRAY RA, PERTSOV AM, JALIFE J: Spatial and temporal organization during cardiac fibrillation. Nature 392: 7578, 1998.

GUTSTEIN DE, MORLEY GE, TAMADONN H, VAIDYA D, SCHNEIDER MD, CHE J: Conduction slowing and sudden arrhythmic death in mice with cardiac-restricted inactivation of connexin43. Circ Res 88: 333-339, 2001.

HAGENDORFF A, SCHUMACHER B, KIRCHHOFF S, LUDERITZ B, WILLECKE K: Conduction disturbances and increased atrial vulnerability in connexin40-deficient mice analyzed by transesophageal stimulation. Circulation 99: 1508-1515, 1999.

HANNA IR, HEEKE B, BUSH H, BROSIUS L, KING-HAGMAN D, DUDLEY SC Jr, BESHAI JF, LANGBERG JJ: Lipid-lowering drug use is associated with reduced prevalence of atrial fibrillation in patients with left ventricular systolic dysfunction. Heart Rhythm 3: 881-886, 2006.

HAUGAN K, OLSEN KB, HARTVIG L, PETERSEN JS, HOLSTEIN_RATHLOU NH, HENNAN JK, NIELSEN MS: The antiarrhythmic peptide analog ZP123 prevents atrial conduction slowing during metabolic stress. J Cardiovasc Electrophysiol 16: 537-545, 2005.

HAYASHI H, WANG C, MYIAUCHI Y, OMICHI C, PAK HN, ZHOU S, OHARA T, MANDEL WJ, LIN SF, FISHBEIN MC, CHEN PS, KARAGUEUZIAN HS: Aging-related increase to inducible atrial fibrillation in the rat model. J Cardiovasc Electrophysiol 13: 801-808, 2002.

HOFFMAN BF, ROSEN MR: Cellular mechanisms for cardiac arrhythmias. Circ Res 49: 1-15, 1981. 
JANSE MJ, WIT AL: Electrophysiological mechanisms of ventricular arrhythmias resulting from myocardial ischemia and infarction. Physiol Rev 69: 1049-1169, 1989.

JANSE MJ, DE BAKKER JMT: Arrhythmia substrate and management in hypertrophic cardiomyopathy: from molecules to implantable cardioverter-defibrillators. Eur Heart J Suppl 3: L15-L20, 2001.

JIANG MT, MOFFAT MP, NARAYAN N: Age-related alterations in the phosphorylation of sarcoplasmic reticulum and myofibrillar proteins and diminished contractile response to isoproterenol in intact rat ventricle. Circ Res 72: 102-111, 1993.

JOYNER RW: Effect of the discrete pattern of electrical coupling on propagation through an electrical syncytium. Circ Res 50: 192-200, 1982.

KIHARA Y, MORGAN JP: Intracellular calcium and ventricular fibrillation. Circ Res 68: 1378-1389, 1991.

KOSTIN S, KLEIN G, SZALAY Z, HEIN S, BAUER EP, SCHAPER J: Structural correlate of atrial fibrillation in human patients. Cardiovasc Res 54: 361-379, 2002.

LAIRD DW: The life cycle of a connexin: gap junction formation, removal and degradation. $J$ Bioenerg Biomembr 28: 311-317, 1996.

LAKATTA EG, GUARNIERI T: Spontaneous myocardial calcium oscillations: are they linked to ventricular fibrillation? J Cardiovasc Electrophysiol 1 4: 473-489, 1993.

LAMPE PD, LAU AF: Regulation of gap junctions by phosphorylation of connexins. Arch Biochem Biophys 384: 205$215,2000$.

LERNER DL, YAMADA KA, SCHUESSLER RB, SAFFITZ JF: Accelerated onset and increased incidence of ventricular arrhythmias induced by ischemia in Cx43-deficient mice. Circulation 101: 547-552, 2000.

MANOACH M, WATANABE Y: How can we facilitate spontaneous termination of ventricular fibrillation and prevent sudden cardiac death? J Cardiovasc Electrophysiol 6: 584-590, 1995.

MANOACH M, TRIBULOVÁ N, VOGELEZANG D, THOMAS S, PODZUWEIT T: Transient ventricular fibrillation and myosin heavy chain isoform profile. J Cell Mol Med 11: 171-174, 2007.

MERRILAT JC, LAKATTA EG, HANO O, GUARNIERI T: Role of calcium and the calcium channel in the initiation and maintenance of ventricular fibrillation. Circ Res 67: 115-1123, 1990.

MITAŠÍKOVÁ M, ŠMIDOVÁ S, MACSALIOVÁ A, KNEZL V, DLUGOŠOVÁ K, OKRUHLICOVÁ L', WEISMANN P, TRIBULOVÁ N: Aged male and female spontaneously hypertensive rats benefit from N-3 polyunsaturated fatty acids supplementation. Physiol Res 47: S39-S48, 2008.

MOE GK, RHEINBOLDT WC, ABILDSKOV JA: A computer model of atrial fibrillation. Am Heart $J$ 67: 200-220, 1964.

MUKHERJEE R, HERRON AR, LOWRY AS, STROUD RE, STROUD MR, WHARTON JM, IKONOMIDIS JS, CRUMBLEY AJ, SPINALE FG, GOLD MR: Selective induction of matrix metalloproteinases and tissue inhibitor of metalloproteinases in atrial and ventricular myocardium in patients with atrial fibrillation. $A m J$ Cardiol 97: 532-537, 2006.

OKRUHLICOVÁ L', TRIBULOVÁ N, MIŠEJKOVÁ M, KUKUČKA M, ŠTETKA R, SLEZÁK J, MANOACH M: Gap junction remodelling is involved in the susceptibility of diabetic rats to hypokalemia-induced ventricular fibrillation. Acta Histochem 104: 387-391, 2002.

OLSSON SB: Atrial fibrillation - where we stand today? J Intern Med 250: 19-28, 2001.

PAPAGEORGIOU P, MONAHAN K, BOYLE NG, SEIFERT MJ, BESWICK P, ZEBEDE J, EPSTEIN LM, JOSEPHSON ME: Site-dependent intra-atrial conduction delay. Circulation 94: 384-389, 1996.

PETERS NS, COROMILAS J, SEVERS NJ, WIT AL: Disturbed connexin 43 gap junction distribution correlates with location of reentrant circuits in the epicardial border zone of healing canine infarcts that cause ventricular tachycardia. Circulation 95: 988-996, 1997.

POLONTCHOUK L, HAEFLIGER JA, EBELT B, SCHAEFER T, STUHLMANN D, MEHLHORN U, KUHNREGNIER F, DE VIVIE ER, DHEIN S: Effects of chronic atrial fibrillation on gap junction distribution in human and rat atria. $J$ Am Coll Cardiol 38: 883-891, 2001.

SAFFITZ JE, SCHUESSLER RB, YAMADA KA: Mechanisms of remodelling of gap junction distribution and the development of anatomic substrates of arrhythmias. Cardiovasc Res 42: 309-317, 1999. 
SALAMEH A, DHEIN S: Pharmacology of gap junctions. New pharmacological targets for treatment of arrhythmia, seizure and cancer? Biochim Biophys Acta 1719: 36-58, 2005.

SEVERS NJ: Gap junction remodelling and cardiac arrhythmogenesis: cause or coincidence? J Cell Mol Med 5: 355$366,2001$.

SCHULZ R, BOENGLER K, TOTZECK A, LUO Y, GARCIA-DORADO D, HEUSCH G: Connexin 43 in ischemic pre- and postconditioning. Heart Fail Rev 12: 261-266, 2007.

SIMOR T, LORAND T, GASZNER B, ELGAVISH GA: The modulation of pacing-induced changes in intracellular sodium levels by extracellular Ca in isolated perfused rat hearts. J Mol Cell Cardiol 29: 1225-1235, 1997.

SPACH MS, HEIDLAGE JF: The stochastic nature of cardiac propagation at a microscopic level. An electrical description of myocardial architecture and its application to conduction. Circ Res 76: 366-380, 1995.

SPACH MS, STARMER CF: Altering the topology of gap junctions a major therapeutic target for atrial fibrillation. Cardiovasc Res 30: 336-344, 1995.

SPACH MS, KOOTSEY JM, SLOAN JD: Active modulation of electrical coupling between cardiac cells of the dog. A mechanism for transient and steady variations in conduction velocity. Circ Res 51: 347-362, 1982.

SPACH MS, HEIDLAGE JF, DOLBER PC, BARR RC: Electrophysiological effects of remodeling cardiac gap junctions and cell size. Circ Res 86: 302-311, 2000.

TEUNISSEN BE, JONGSMA HJ, BIERHUIZEN MF: Regulation of myocardial connexins during hypertrophic remodeling. Eur Heart J 25: 1979-1989, 2004.

TRIBULOVÁ N, VARON D, POLACK-CHARCON S, BUSCEMI P, SLEZÁK J, MANOACH M: Aged heart as a model for prolonged atrial fibrilo-flutter. Exp Clin Cardiol 4: 64-72, 1999.

TRIBULOVÁ N, MANOACH M, VARON D, OKRUHLICOVÁ L', ZINMAN T, SHAINBERG A: Dispersion of cellto-cell uncoupling precedes of low $\mathrm{K}^{+}$-induced ventricular fibrillation. Physiol Res 50: 247-259, $2001 \mathrm{a}$.

TRIBULOVÁ N, SEKI S, MANOACH M, TAKEDA H, OKRUHLICOVÁ L', MOCHIZUKI S: Restoration of basal cytoplasmic $\mathrm{Ca}^{2+}$ and recovery of intermyocyte coupling precede stobadine-induced ventricular defibrillation in whole heart preparation. Eur Heart $J$ 22: A547, 2001 b.

TRIBULOVÁ N, OKRUHLICOVÁ L', NOVÁKOVÁ S, PANCZA D, BERNÁTOVÁ I, PECHANOVÁ O, WEISMANN P, MANOACH M, SEKI S, MOCHIZUKI M: Hypertension-related intermyocyte junction remodeling is associated with higher incidence of low $\mathrm{K}^{+}$- induced lethal arrhythmias in isolated rat heart. Exp Physiol 87: 195-205, 2002a.

TRIBULOVÁ N, OKRUHLICOVÁ L', VARON D, MANOACH M, PECHANOVÁ O, BERNÁTOVÁ I, WEISMANN P, BARANČÍK M, STYK J, SLEZÁK J: Structural substrates involved in the development of severe arrhythmias in hypertensive rat and aged guinea pig hearts. In: Cardiac Remodeling and Failure, SINGAL P, DIXON I, KIRSCHENBAUM L, DHALLA NS (eds), Kluwer Academic Publishers, Boston, USA, 2002b, pp 377-398.

TRIBULOVÁ N, OKRUHLICOVÁ L', IMANAGA I, HIROSAVA N, OGAWA K, WEISMANN P: Factors involved in the susceptibility of spontaneously hypertensive rats to low $\mathrm{K}^{+}$- induced arrhythmias. Gen Physiol Biophys 22: 369-382, 2003.

TRIBULOVÁ N, KNEZL V, OKRUHLICOVÁ L', DŘíMAL J, LAMOŠOVÁ D, SLEZÁK J, STYK J: L-thyroxine increases susceptibility of young rats to low $\mathrm{K}^{+}$-induced ventricular fibrillation while facilitates sinus rhythm restoration in old one. Exp Physiol 89: 629-636, 2004.

TRIBULOVÁ N, DUPONT E, SOUKUP T, OKRUHLICOVÁ L, SEVERS NJ: Sex differences in connexin-43 expression in left ventricles of aging rats. Physiol Res 54: 705-708, 2005.

TRIBULOVÁ N, FIALOVÁ M, DLUGOŠOVÁ K, KNEZL V, OKRUHLICOVÁ L, KRISTEK F, ZICHA J, KUNEŠ J. Myocardial gap junction remodelling in hypetriglyceridemic rat heart is associated with increased vulnerability to ventricular fibrillation. Cardiology 15 (Suppl 1): 32S-33S, 2006.

TRIBULOVÁ N, KNEZL V, FIALOVÁ M, DLUGOŠOVÁ K, OKRUHLICOVÁ L. Fish oil likewise atorvastatin decrease susceptibility of hypetriglyceridemic rat hearts to ventricular fibrillation. European Heart $J \mathbf{2 8}$ (Abstract Suppl): 29, 2007. 
TURNER MS, HAYWOOD GA, ANDREKA P, YOU L, MARTIN PE, EVANS H, WEBSTER KA, BISHOPRIC NH: Reversible connexin 43 dephospohorylation during hypoxia and reoxygenation is linked to cellular ATP levels. Circ Res 95: 726-733, 2004.

VAN DER VELDEN HMW, AUSMA J, ROOK MB, HELLEMONS AJCGM, VAN VEEN TAAB, ALLESSIE MA, JONGSMA HJ: Gap junctional remodeling in relation to stabilization of atrial fibrillation in the goat. Cardiovasc Res 46: 476-486, 2000.

WACHTELL K, DEVEREUX RB, LYLE PA: The effect of angiotensin receptor blockers for preventing atrial fibrillation. Curr Hypertens Rep 9: 278-283, 2007.

WANG YG, HUSER J, BLATTER LA, LIPSIUS S: Withdrawal of acetylcholine elicits Ca-induced delayed afterdepolarizations in cat atrial myocytes. Circulation 96: 1275-1281, 1997.

WIJFFELS MCEF, KIRCHHOFF CHJHJ, DORLAND R, ALLESIE A: “AF begets AF” a study in awaked chronically instrumented goats. Circulation 92: 1954-1968, 1995.

WINFREE AT: Rotating solutions to reaction diffusion equations in simply connected media. SIAM-AMS Proc 8: 1331, 1974.

WITKOWSKI FX, LEON LJ, PENKOSKE PA, GILES WR, SPANO ML, DITTO WL, WINTRE AT: Spatiotemporal evolution of ventricular fibrillation. Nature 392: 78-82, 1998.

ZAITSEV AV, BERENFELD O, MIRONOV SF, JALIFE P, PERTSOV AM: Distribution of excitation frequencies on the epicardial and endocardial surfaces of fibrillating ventricular wall of the ship heart. Circ Res 86: 408-417, 2000.

ZICHA L, DOBEŠOVÁ Z, KUNEŠ J: Late effects of early intervention: transient captopril treatment of SHR in juvenile critical period for hypertension. Physiol Res 55: 5P, 2006a.

ZICHA L, PECHÁŇOVÁ O, ČAČÁNYIOVÁ S, CEBOVÁ M, KRISTEK F, TŐRŐK J, ŠIMKO F, DOBEŠOVÁ Z, KUNEŠ J: Hereditary hypertriglyceridemic rat: a suitable model of cardiovascular disease and metabolic syndrome? Physiol Res 55 (Suppl 2): S49-S63, 2006b.

ZIPES DP, WELLENS HJJ: Sudden cardiac death. Circulation 98: 2334-2351, 1998. 